\title{
A Pedagogical Perspective on the Acquisition of Spanish Writing and Speaking Skills
}

By Joel Laffita Rivera

Multimedia University

Abstract- The research study aimed to deliver a pedagogical perspective on the acquisition of Spanish writing and speaking skills. A research study prospect and methodological schemes in association with the objective of the study has been charted. The study has used the mixed method approach for the collection of data and its analysis. The outcome revealed that the acquisition of the Spanish language writing and speaking skills could be enhanced, empowered and partially retained as a result of using an array of approaches based on delivering phrases and sentence constructions into Spanish written and spoken dialogues and paragraph contexts. It also showed that this practice tends to infuse cognitive skills and developing language competences among Spanish language learners up beginner's level whose second language is English. The present study is very valuable for Spanish/English bilingual language teachers to deliver assignments based on the acquisition of Spanish writing and speaking skills.

Keywords: writing; speaking; syntax; lexicon; sentence construction; pragmatic; phonetic.

GJHSS-G Classification: FOR Code: 200399

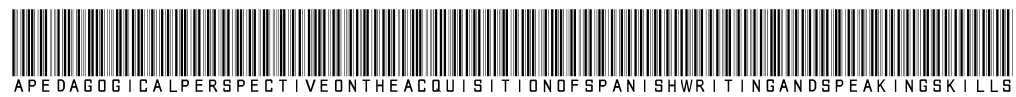

Strictly as per the compliance and regulations of:

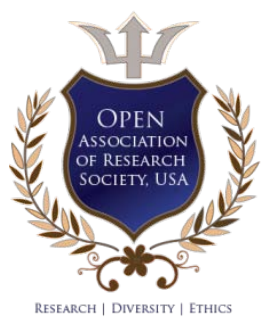

(C) 2020. Joel Laffita Rivera. This is a research/review paper, distributed under the terms of the Creative Commons AttributionNoncommercial 3.0 Unported License http://creativecommons.org/licenses/by-nc/3.0/), permitting all non-commercial use, distribution, and reproduction in any medium, provided the original work is properly cited. 


\title{
A Pedagogical Perspective on the Acquisition of Spanish Writing and Speaking Skills
}

\author{
Joel Laffita Rivera
}

\begin{abstract}
The research study aimed to deliver a pedagogical perspective on the acquisition of Spanish writing and speaking skills. A research study prospect and methodological schemes in association with the objective of the study has been charted. The study has used the mixed method approach for the collection of data and its analysis. The outcome revealed that the acquisition of the Spanish language writing and speaking skills could be enhanced, empowered and partially retained as a result of using an array of approaches based on delivering phrases and sentence constructions into Spanish written and spoken dialogues and paragraph contexts. It also showed that this practice tends to infuse cognitive skills and developing language competences among Spanish language learners up beginner's level whose second language is English. The present study is very valuable for Spanish/English bilingual language teachers to deliver assignments based on the acquisition of Spanish writing and speaking skills.
\end{abstract}

Keywords: writing; speaking; syntax; lexicon; sentence construction; pragmatic; phonetic.

\section{InTRODUCTION}

$\mathrm{H}$ aving the "perfect" Spanish teaching methodology is still far from being the approach that all Spanish language teachers aspire. Nevertheless, continue searching for it by working in that direction will lead us to benefit the process of the Second Language Acquisition (SLA). The writing skill in Spanish language is subjected among many linguistic themes to grammatical and lexicon functions that are putting into a words-order governed by the Spanish language writing system. On the other hand, the speaking skill is not only subjected to such syntax and vocabulary applications and words-order but also phonetic, pragmatic, and sociocultural Spanish language issues too. According to Linguistics, syntax addresses the set of rules, principles, and processes that govern the structure of a sentence in a given language. Similarly, concept of appropriateness but referring to lexicon has been stated by (English Oxford Living Dictionaries, 2018) when it comes to a given language. This concept clearly highlights that vocabulary is the body of words used in a particular language. Seen this from a perspective of language distinctiveness, it could be affirmed that these linguistic conceptualities are also relevant to what is the Spanish grammar definition stated by (Diccionario de la Lengua Española 23a Edición, 2015), which defines Spanish grammar as the grammar of this language. Thus, setting

Author: Faculty of Applied Communication (FAC) Multimedia University, Malaysia.e-mail: Joel.laffita@mmu.edu.my an array of strategies for teaching and learning the writing and speaking skills in the Spanish language context requires being aware of these concept insights that capitalize on the linguistic peculiarities that a given language does posse. The significance of taking into consideration the own Spanish language orthography, phonetic, syntax, and lexicon traits when teaching and learning this language subject has been discussed for other researchers (Rivera, 2019). The complexities of Spanish own syntax and lexicon, and phonetical characteristics often create discomfort among teachers and learners when handling the teaching and learning of the writing and speaking skills in the Spanish language context. Due to these complexities, it continues to be a challenge from teachers making Spanish novice learners gets the ability to write grammatically correct phrases and sentences and speaking them that way too in a Spanish language context. However, even though this is a complex methodological task; Spanish language teachers can treat and trace the level of language proficiency of these learners by getting adequate methodology assistance. Thus, this research study is setting up a pedagogical perspective which emphasizes on the acquisition of the Spanish language writing and speaking skills. These linguistic competences could be enhanced, empowered and subsequently partially retained by using an array of approaches based on delivering phrases and sentence constructions into written and spoken dialogues and paragraph contexts. This methodological practice tends to infuse cognitive skills and developing language competences among Spanish language learners up beginner's level whose second language is English. Therefore, taking these accounts as a point of departure, a research study prospect is putting forward.

\section{Literature ReView}

Although numerous researcher-studies have undertaken regarding the acquisition of Language Learning (Bialystok, 1981); (Batchelor, Ronald, Ernest, San José, José, Miguel, 2010); (Castañeda, 1997); August \& Carlo, 2002); the present study is meant to provide an exclusive pedagogical perspective for treating the writing and speaking skills in Spanish language context when referring to the acquisition of these two abilities. The productive of the language are writing and speaking, cited by (Ehsan Namaziandost; Akram Abdi Saray; Fariba Rahimi Esfahani, 2018). 
Based on this pragmatic argument, I would say that perhaps there are not better ways to assignment Spanish learner's second language capabilities than using for it writing and speaking skills tests. Lexically and grammatically speaking, I would affirm that these two skills are interconnected, so lexicon and grammar patterns are vital components when writing or taking as appropriate in a given language. (Hyland, 2003) argues that acquiring an appropriate level of linguistic bases is essential for developing writing skill to empower students to overcome a range of lexical and grammatical skills needed for writing progression. Writing commonly pursues a standardized form of grammar, structure, and vocabulary which is inextricable from the structure of spoken sentences; writing practice not only aggrandizes students' vigilant notification of the sentence structures while speaking but promotes their speaking proficiency (Silva, 1990). The speaking skill is defined as a characterized interpersonal function of language through which meaning is created and transmitted (Hughes, 2013). Speaking is also described as an interactive process of constructing meaning that involves producing and receiving and processing information. In this aspect, not only know how to use specific points of language such as grammar, pronunciation or vocabulary will be necessary, but also how significant it could be for language learners to understand when, where, why and in what ways to produce language. Based on all these pragmatic arguments, one could say that for getting right the ability of writing and speaking, it would be necessary to know about phrases and sentence constructions, syntax and lexicon, phonetic and pragmatic issues in a given language. Linguistically speaking this is something on which Spanish language teachers have to emphasize to better treating the writing and speaking skills in a Spanish language context. And from the standpoint of getting this right; teachers should strive to create, update and review instructional settings, materials, and strategies as (Tenku \& Chow, 2017) suggest since an effective-language-teaching requires putting into practice an array of teaching strategies because there is no single, universal approach that suits all situations.

\section{ili. Study Rational Inclusions}

Integrating teaching and learning strategies to lecturing the writing and speaking skills in Spanish language classroom settings has never been an easy task to accomplish. By taking into account the complexities of linguistic functions that this language subject does have and which are subject to its writing and phonetical system; I would say that it continues being the pedagogical challenge for Spanish language teachers to overcome it. In comparison to many other European languages including English, Spanish has a much more complex writing system, and even though many are of the right opinion that Spanish is a phonetic language and one of the most easy foreign languages to learn because of it; the fact will never be just about easiness, but about a phonetical system that involves a series of linguistic functionalities unique to Spanish language. Thus, Spanish/English bilingual language teachers must look at those linguistic issues related to the writing and speaking skills from the exclusive perspectives of Spanish language writing and phonetical system to setup appropriate teaching strategies to treat the acquisition of the writing and speaking skills in the Spanish language context. In this respect, like Spanish language teachers, we have to have in mind the way we should access Spanish novice learners' learning writing skill, which is not just that ability for these learners to acquire but also the method provided to help them to develop it. It is believes that one of the reasons for which Spanish language novice learners frequently mistake when writing in this language context is associated with the level of difficulties that the language subject presents in terms of grammar and vocabulary structures, nevertheless, as Spanish language teachers we can relate to phrase and sentence constructions to transfer not just easy syntax and lexicon patterns but the moderate and difficult too. And as per speaking skill refers, most of the phonetic mistakes that Spanish language novice make are related to "linguistic-interconnected-issues" such as syntax; lexicon; phonetic and pragmatic. So, these are academic language teaching and learning concerns to be focused and not to be taken as assumptions because of the language-level mistake-expectances. As efficient, we treat the writing skill as such will be the output of the speaking as well.

\section{Methodological Schemes}

Producing Spanish language novice's learners capable of writing with accuracy, clarity, and coherence phrases and sentences into Spanish language contextual dialogues and paragraphs is an achievable goal. And making them delivering those statements into spoken discourses with clearness, fluency, coherence, and through which they can demonstrate command of Spanish linguistic capabilities is also possible. In terms of writing, it is essential to make Spanish novice learners knowing how phrases and sentences work in this language because of their written and spoken role. While dialogue can be written by using a variated linguistic format; we cannot compose in the same way a written paragraph. A well-composed text is "a compendium of various sentences putting into a linguistic logical order according to the writing system of a given language". And when it comes to spell out verbally those sentences and phrases is not about pronouncing word by word the sentences and phrases constructions; it is about to put them into discourses by 
using adequate grammar and vocabulary words; phonetic, pragmatic, and sociocultural issues that will lead to communicate well in conversational Spanish.

\section{a) Writing Inputs}

Writing is a form of communication that allows students to write or type their thoughts on paper and computer, to organize their knowledge into convincing arguments, and to convey meaning through wellconstructed text. There are some essential methodological skills needed for Spanish language teachers to access Spanish novice learners' written phrases and sentences and paragraphs assignments in a Spanish language context. These abilities are related to the writing system of the Spanish language. According to the orthography of this language, there is a difference between a phrase and a sentence. Generally the first is used to represent "an idea". (Hola, Buenos días.). And the second something more complete "a sentence" (¿Cómo te llamas?). Mostly a sentence is made up of two principal parts "subject" a person or a thing of which we say something and the "predicate", which the subject usually describes. For example, subject (Yo / él / ellos), predicate (soy Luis / es José / son Luis y José). So, we can relate to these basic linguistics principles to make Spanish novice learners begin understanding the differences between phrases and sentences as well as the SVO (Subject+verb +object) of simple sentence constructions in a Spanish language context. This methodology insight will helps Spanish novice learners start differentiating not just the Spanish syntax and lexicon used in phrases and sentence constructions but also their contextual word-order. For instance, when it comes to writing a dialogue based on meeting people, the subject-knowledge-domain to acquire is usually transferred through a series of statements such as greetings, introductions, questions, common courtesy, responding, and farewells. Seen this from a linguistics perspective, it means that the use of phrases, interrogative sentences, simple sentences, and selected syntax and vocabulary patterns will be required. Therefore, based on this pedagogical knowledge, we can equip Spanish novice learners with distinct pragmatic-writing-brainstorming that allows them to develop cognitive skills and language competences from the very beginning of the Spanish language teaching and learning process. See table 1: Dialogue Writing Brainstorming and table 2: Paragraph Writing Brainstorming:

Table 1: Dialogue Writing Brainstorming

\begin{tabular}{|c|c|c|c|}
\hline $\begin{array}{c}\text { Subject Knowledge } \\
\text { Domain }\end{array}$ & Phrase-Constructions & Sentence-Constructions & Pragmatic-Focus \\
\hline $\begin{array}{l}\text { Informal Greetings; } \\
\text { greetings; self-introduction; } \\
\text { Nationality and place of } \\
\text { origin; career and place of } \\
\text { Study and grade; age; } \\
\text { fare wells. }\end{array}$ & $\begin{array}{c}\text { Hola. } \\
\text { Buenos días. } \\
\text { Buenas tardes. } \\
\text { Buenas noches. } \\
\text { Mucho gusto. } \\
\text { Encantado. } \\
\text { Encantada. } \\
\text { Lo siento. } \\
\text { iOh! yo también. } \\
\text { Igualmente. } \\
\text { Bueno. } \\
\text { Adiós. } \\
\text { Hasta luego. } \\
\text { Hasta mañana. }\end{array}$ & 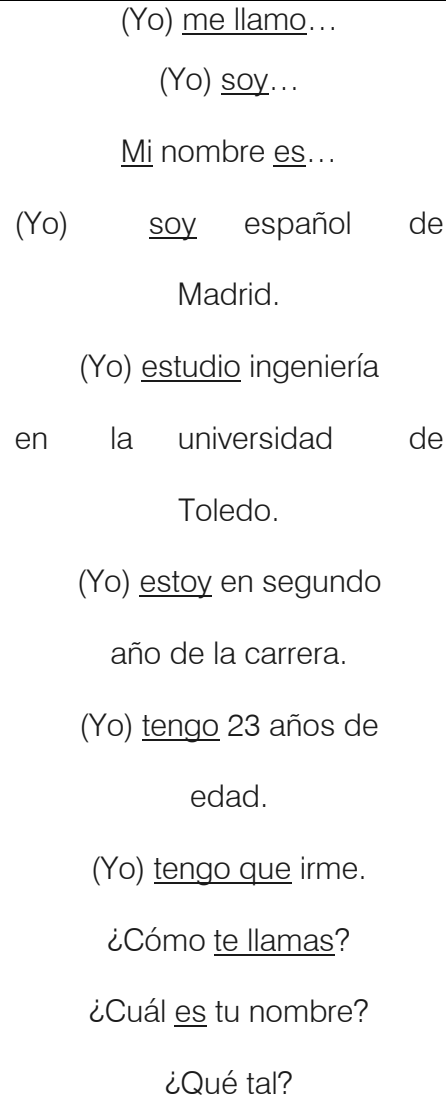 & $\begin{array}{l}\text { Dialogue-starters. } \\
\text { Dialogue-endings. }\end{array}$ \\
\hline
\end{tabular}




\begin{tabular}{|c|c|c|}
\hline & & $\begin{array}{c}\text { ¿Cómo estás? } \\
\text { ¿De dónde eres? } \\
\text { ¿A qué te dedicas? } \\
\text { ¿Qué haces, trabajas o } \\
\underline{\text { estudias? }}\end{array}$ \\
\hline & & $\begin{array}{c}\text { ¿Qué estudias? } \\
\text { ¿Cuántos años tienes? }\end{array}$ \\
\hline
\end{tabular}

Table 2: Paragraph Writing Brainstorming

\begin{tabular}{|l|l|l|}
\hline \multicolumn{1}{|c|}{ Subject Knowledge Domain } & \multicolumn{1}{|c|}{ Descriptive Paragraph Context } & \multicolumn{1}{c|}{ Pragmatic Writing-Focus } \\
\hline $\begin{array}{l}\text { Self-introduction; nationality and } \\
\text { place of origin; career and place of soy Pablo. Soy español de Madrid. } \\
\text { study and grade; age. }\end{array}$ & $\begin{array}{l}\text { Soy estudiante, estudio ingeniería en la } \\
\text { universidad de Toledo, estoy en segundo construction (SVO) syntax and } \\
\text { año de la carrera. Tengo 23 años de } \\
\text { edad... }\end{array}$ & $\begin{array}{l}\text { lexicon and word- order; punctuation; } \\
\text { gender- usage }\end{array}$ \\
\hline
\end{tabular}

As can be seen, whether is a dialogue or paragraph; a well-organized piece of writing has to be clear and presented in a way that is logical and aesthetically pleasing. Hypothetically speaking image, for instance, if as a Spanish language novice learner, I have been instructed in the way presented before carrying out the writing tasks given. Perhaps as a Spanish novice learner I might have been better prepared to perform in a similar way as well. Thus, based on the pedagogical insights, prior exposed Spanish teachers can design and provide writingbrainstorming even to introduce topics related to

Table 3: Dialogue Writing Brainstorming Usted Address Forms

\begin{tabular}{|c|c|c|c|}
\hline Subject Knowledge Domain & Phrase-Constructions & Sentence-Constructions & Pragmatic-Focus \\
\hline $\begin{array}{l}\text { Formal Greetings; greetings; self- } \\
\text { introduction; nationality and place of } \\
\text { origin; career and place of study and } \\
\text { grade; age; farewells. }\end{array}$ & $\begin{array}{l}\text { Buenos días. } \\
\text { Buenas tardes. } \\
\text { Buenas noches. } \\
\text { Mucho gusto. } \\
\text { Es un placer. } \\
\text { Encantado. } \\
\text { Encantada. } \\
\text { Adiós. } \\
\text { Hasta mañana. }\end{array}$ & $\begin{array}{l}\text { (Usted) se llama... } \\
\text { (Usted) es... } \\
\text { Su nombre es... } \\
\text { (Usted) es español de } \\
\text { Madrid. } \\
\text { (Usted) } \underline{\text { estudia }} \\
\text { ingeniería en la } \\
\text { universidad de Toledo. } \\
\text { (Usted) está en segundo } \\
\text { año de la carrera. } \\
\text { (Usted) tiene } 23 \text { años de } \\
\text { edad. } \\
\text { ¿Cómo se llama? } \\
\text { ¿Cuál es su nombre? }\end{array}$ & $\begin{array}{l}\text { Dialogue-starters. } \\
\text { Dialogue-endings }\end{array}$ \\
\hline
\end{tabular}

Sociocultural-issues. For instance, change the content of table 1 to introducing formal-linguistic-issues such as the address-forms for "usted", which is related to the Hispanic concept of proper etiquette. And regarding table 2 using the syntax-patterns associated to the Spanish personal pronoun "usted" to help Spanish novice learners write about the $3^{\text {rd }}$ singular person (my classmate, my best friend), etc. See table 3 Dialogue Writing Brainstorming Usted Address Forms and Table 4 Paragraph Writing Brainstorming $3^{\text {rd }}$ Person Verb Forms. 


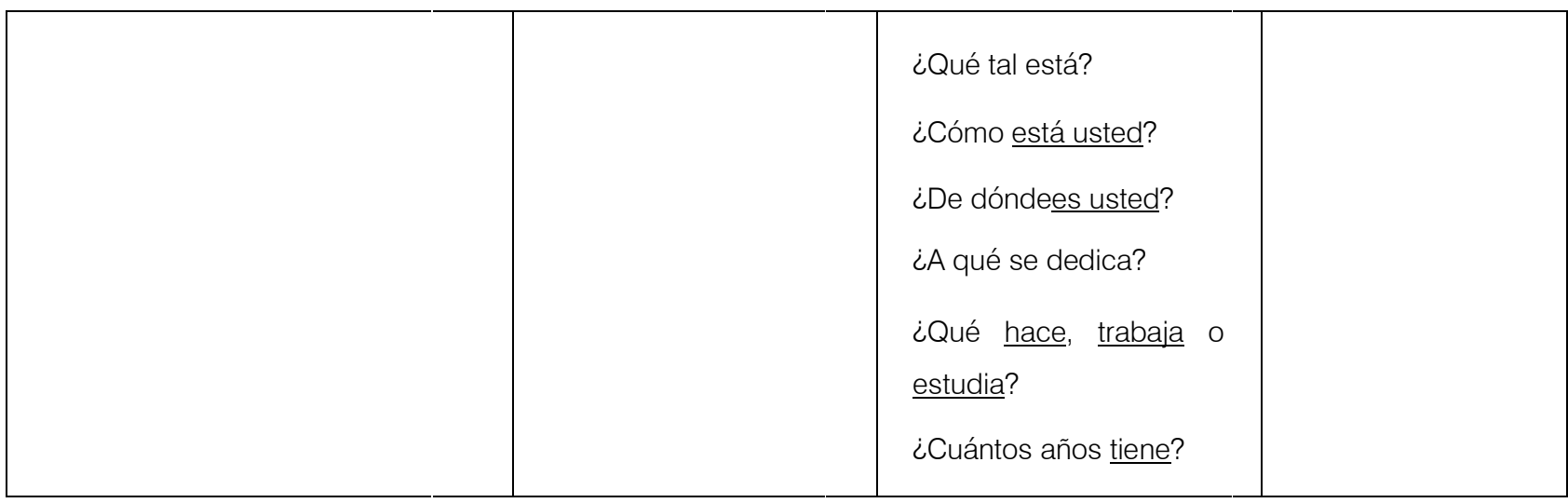

Table 4: Paragraph Writing Brainstorming $3^{\text {rd }}$ Person Verb Forms

\begin{tabular}{|c|c|c|}
\hline Subject Knowledge Domain & Descriptive Paragraph Context & Pragmatic Writing-Focus \\
\hline $\begin{array}{l}\text { Subject: My classmate: himself/ } \\
\text { herself introduction; nationality and } \\
\text { place of origin; career and place of } \\
\text { study and grade; age. }\end{array}$ & $\begin{array}{l}\text { Mi compañero-a de clase se llama Ana. Es } \\
\text { español-a de Madrid. Es estudiante, estudia } \\
\text { ingeniería en la universidad de Toledo, está } \\
\text { en segundo año de la carrera. Tiene } 23 \text { años } \\
\text { de edad... }\end{array}$ & $\begin{array}{l}\text { Sentence construction (SVO) } \\
\text { syntax and lexicon and word- order; } \\
\text { punctuation; gender- usage }\end{array}$ \\
\hline
\end{tabular}

That writing method with not doubt will catapult Spanish language novice learners into a higher linguistic level of second language acquisition competences. And a similar pedagogical practice could be used in more advanced linguistic levels as other topics related to personal data and descriptions are taught, which will require distinct grammar focus functions treatment (Rutherford, 1988).

\section{b) Speaking Inputs}

Speaking is that interactive process of constructing meaning that involves producing and receiving and processing information. It depends on the context, or situation in which it carries out. It requires learners to not only know about specific points of language such as grammar, pronunciation or vocabulary but also to understand when, where, why, and in what ways to create language. There are some essential methodological skills needed for Spanish language teachers to access Spanish language novice learner's speaking competence. These abilities are partially related to the writing system of this language, as it has been previously discussed. And as per Spanish phonetical arrangement refers; other than knowing about consonant alphabet letters pronunciation and relevant added phonetical issues such as hiatus; the use of conjunctions; interjections; dieresis and division of syllables; Spanish language teachers have to emphasis on vowels pronunciation, the formation of diphthong and triphthongs; the use tilde and linking. Based on this fact, the study is highlighting the following linguistic statements regarding these four phonetical associated language components for Spanish teachers to enhance better and empower Spanish language novice learner's language phonetical capabilities:

\section{- $\quad$ Spanish Vowels Patterns}

Phonetical English/Spanish Transcript (a/ah/e/ eh/i/ee/o/oh/u/oo/), even though there are some phonetical variations among Spanish language native speakers from different Spanish speaking countries regions; this is a simple and practical phonetical tool that Spanish/English bilingual teachers can use to access Spanish novice learners from the very beginning of the learning process.

\section{- Spanish diphthong and triphthongs Patterns}

The diphthongs are made up by combining the strong vowels which are $(\mathrm{a} / \mathrm{e} / \mathrm{o})$ plus the weak one (i/u), and obi-verse. The same arrangement usually happens with the formation of triphthongs and hiatus. In the case of the hiatus, the weak vowel is stressed and two strong vowels make up hiatus too.

Diphthongs: agua / aire / cielo / oigo / ruido / Triphthongs: Uruguay / Paraguay / apreciéis Hiatus: vehículo / ahínco / ahogar / almohada

\section{- $\quad$ Spanish Tilde Patterns}

The use of "tilde" on any of the Spanish vowels (á / é / i / ó / ú) has significant influence when it refers to voice-articulation; the vowel that carries it indicates that the voice goes up in the syllable where that vowel is stressed: educación / profesión / matemática / ángel. This graphical accent "tilde" is also used to differentiate many Spanish words with the same spelling:

Mi (possessive adjective) mí (pronoun)./ Mas (in addiction) más (conjunction). / público (noun) publicó

(verb) publico (verb) ext.

- $\quad$ Spanish Linked Phonetical Patterns

In spoken Spanish, words are not pronounced separated in phrase or sentence, being this one of the 
reasons for which the use of "linking" is a practice to be focused when speaking Spanish. This kind of connection is produced when the last consonant of the word and the initial vowel of the other one are linked in one sound, when two identical vowels are linked in one sound, and when two identical consonants are linked as well:

$$
\begin{aligned}
& \text { Ana tiene un niño. } \\
& \text { La abeja es un insecto. } \\
& \text { El oso es un animal. } \\
& \text { ¿Cómo se escribe? }
\end{aligned}
$$$$
\text { Mi nombre es. }
$$

Those four phonetical associated components are of the most relevant when it comes to help Spanish language novice learners getting the ability to speak in Spanish language context as appropriate. Thus, we can relate to that linguistics knowledge to equip these learners with what is required for them to accomplish the language goal wanted. Due to the linguistic peculiarities that the Spanish writing-system does have, it will not be as difficult to transmit these cognitive skills. For instance, Hola, Buenos días is a phrase that requires the use of a silenced-letter " $h$ ", diphthong "ue" and tilde "i" to break the diphthong. ¿Cómo te llamas? / ¿De dónde eres? both are interrogative sentences that require the use of question marks "¿...?)", tilde "ó", distinct grammar patterns "te llamas", "eres-tú-address-form", the peculiar sound of the double letter "II", and the active and passive voice involvement and linking. So, when it comes to spelling out verbally these entire phrases and sentences in Spanish, all these associated phonetical issues matter.

- Hola, ¿qué tal?

- Muy bien, ¿y tú?

- Muy bien también. Me llamo... ¿Cómo te llamas?

- Soy... Mucho gusto.

- Encantado. Bueno, hasta luego.

- Hasta luego Subject knowledge domain (speaking)

\section{Informal Greetings;}

greetings; self-

introduction; questions;

common courtesy; responding; farewells

\section{Formative Spoken Assignment}

Another speaking skill point that will help Spanish language novice learners perform as appropriate in this field is to equip them with basic knowledge about dialogue constructions. For instance, Hola,Bbuenos días / Hola, Buenas tardes / Hola, Buenas noches, Adiós, Hasta luego, Hasta mañana are phrases that no one would say without taking into account the time of day and goodbye. So, here is the main purpose about when using these statements. Seen it from a pragmatic perspective, it means "dialoguestarters and dialogue-endings". ¿Cómo te llamas? / ¿De dónde eres? / ¿Qué tal? / ¿Cómo estás? / Mucho gusto / Es un placer / Encantado / Encantada / Igualmente / Estoy bien / Estoy muy bien / Regular. These are questions, common courtesy and responding that no one would ask or say without having a command of the subject- knowledge-domain they refer to in a given language. And this is why it is important to equip Spanish language novice learners with a writing brainstorming based on dialogue phrases and sentence constructions and pragmatic insights, as prior suggested. Even though we can provide learners a model of a constructed dialogue; I would personally suggest taking into account the benefits that a selflearning language setting approach can produce in terms of writing and speaking skills outputs when it comes to delivering a formative written assignment. See the diagram of the dialogue comparison structure:

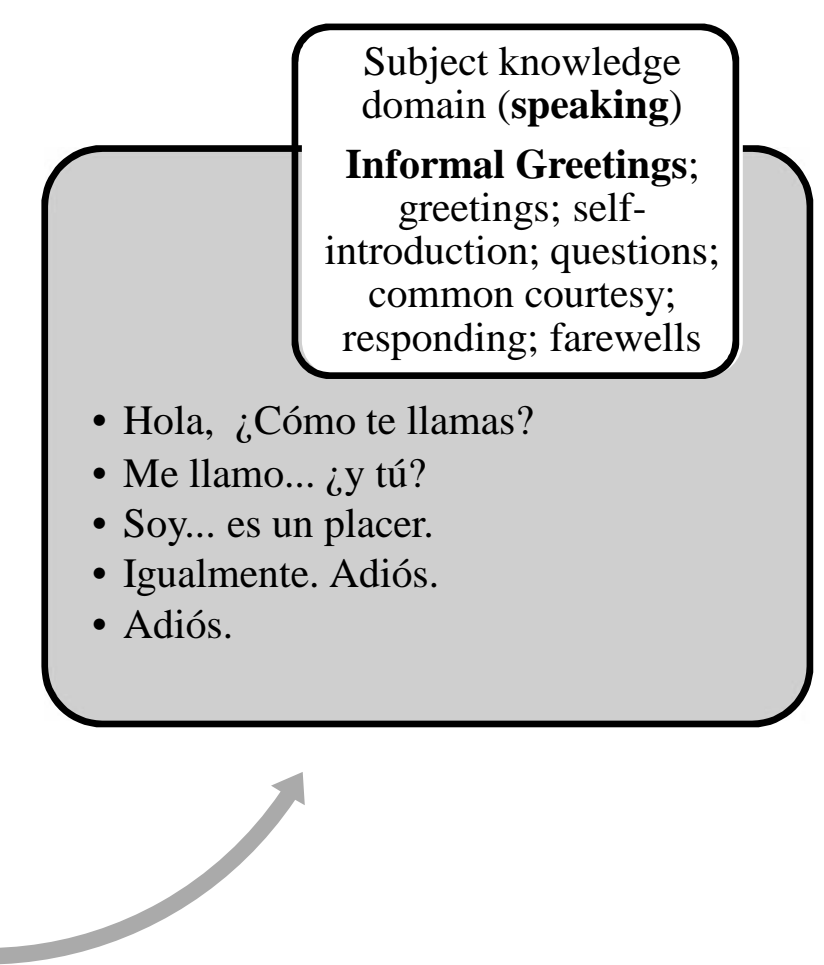


As can be observed, the content of the two written illustrated dialogues has been subjected to the "subject-knowledge-domain" given. So, learners can perform language learning inputs independently. As Spanish language teachers, we can relate to the linguistic functions of the phrases and sentences used for Spanish language novice learners to acquire and develop cognitive skills and language competences. It is affirmed that language teaching involves knowing the theory of both linguistic and language learning and teaching. Thus, teachers should consider providing linguistic techniques through which Spanish language novice learners get a good understanding of what is to be taught when writing and speaking is refers. Even though the acquisition of these two significant linguistic skills is a complex task to accomplish, teachers can access the Spanish language novice learner's language proficiency level of both competences by putting into pedagogical perspectives the methodological schemes inputs provided in this research study. As well as teachers used to prepare themselves in terms of designing and setting their teaching plans before delivering lesson-contents; they should also provide the materials required to support Spanish novice learners writing and speaking skills acquisition.

\section{Study Methodology}

A methodical review of classroom language teaching and learning setting; available teaching and learning materials and language teaching and learning curriculum standards; publications; Internet webpages were performed with the goal of strengthening and validating the framework of this research study. The research study compressed of three main questions which were accountable for leading the research-based study objective and to respond the research concern issues prior exposed.

\section{Vil. Research Questions}

- Can we as Spanish language teachers produce Spanish language novice learners able to write with accuracy, clarity and coherence phrases and sentences into Spanish language contextual dialogues and paragraphs?

- Can we as Spanish language teachers make Spanish language novice leaners delivering phrases and sentences into spoken discourses with clearness in terms of pronunciation, fluency, coherence and through which they can demonstrate command of Spanish linguistic capabilities?

- How much do we as Spanish language teachers know about the linguistic applications of the Spanish language writing and phonetical system?

\section{Vili. Research Techniques Background}

Employing principles of research techniques based on the collection of data and its analysis the study began gathering data from a monitory of Spanish language academic teaching and learning that was in place for one trimester, which is composed by 14 weeks with three loading credit hours per week, $43 \mathrm{hrs}$. in total. The number of students involved was 120 from three different class-sections. The pedagogical observations were based on analyzing the teaching delivering mode of the writing and speaking skills when working with Spanish language novice in a Spanish classroom context as well as the outputs of the methodological perspective presented in this research study. As per available learning material it refers, the study searched Spanish language modules such as Nuevo ELE Indicial 1 (Virgilio, 2015) and (((Eco))) A1 (Alfredo and Carlos, 2015) and the Spanish language book Basic Spanish (Ana, Jarvis, Francisco, 2014) used in these Spanish language classes to find out what is stated in their content related to the subject-matter-domain discussed in this research, manly the practicality of teaching and learning strategies to access Spanish language novice writing and speaking skills. Similarly, the research study searched for various research publications which have been added chronologically in the referential heading. Additionality, a revision of the Marco Común Europeo de Referencia para las Lenguas: aprendizaje, enseñanza, evaluación (Consejo de Europa, 2001) and the (American Council on the Teaching of Foreign Languages, 2012) curriculum standards designed for teaching and learning the Spanish language according to the level of language teaching and learning $A 1$ or Beginners which are the levels named according to the parameters of these two organizations. See Table 5 Spanish language Novice Level Equivalent and other levels as well: 
Table 5: Spanish Language Novice Level Equivalent

\begin{tabular}{|c|c|c|c|c|c|}
\hline \multicolumn{6}{|c|}{ CORRESPONDENCIAS } \\
\hline NIVELES & $\begin{array}{l}\text { D.I.E. } \\
\text { ORAL }\end{array}$ & $\begin{array}{c}\text { D.I.E. } \\
\text { ESCRITO }\end{array}$ & $\begin{array}{c}\text { D.I.E. } \\
\text { ONLINE- } \\
\text { ESCRITO }\end{array}$ & $\begin{array}{c}\text { Marco Común Europeo de } \\
\text { Referencia para las } \\
\text { Lenguas }\end{array}$ & $\begin{array}{c}\text { ACTFL } \\
\text { American Council on the } \\
\text { Teaching of Foreign } \\
\text { Languages }\end{array}$ \\
\hline \multirow[t]{2}{*}{ Elemental } & 1 & & & & Novice Low \\
\hline & 2 & Elemental & Elemental & A1 & Novice Mid \\
\hline \multirow[t]{2}{*}{ Básico } & 3 & & & & Novice High \\
\hline & 4 & Básico & Básico & A2 & Intermediate Low \\
\hline \multirow[t]{2}{*}{ Intermedio } & 5 & & & & Intermediate Mid \\
\hline & 6 & Intermedio & Intermedio & B1 & Intermediate High \\
\hline \multirow[t]{2}{*}{ Avanzado } & 7 & & & & Advanced Low \\
\hline & 8 & Avanzado & Avanzado & B2 & Advanced Mid \\
\hline Superior & 9 & Superior & Superior & C1 & Advanced High \\
\hline Dominio & 10 & Dominio & Dominio & $\mathrm{C} 2$ & Superior \\
\hline $\begin{array}{c}\text { Especializa } \\
\text { dos }\end{array}$ & $\begin{array}{l}\text { - Negocios } \\
\text { - Turismo } \\
\text { - Salud }\end{array}$ & Especializado & Especializado & - & - \\
\hline
\end{tabular}

\section{iX. Research Field Focus}

Generally, this research study was limited to analyze the acquisition of the writing and speaking skills in Spanish language practices. The population and place to examine and trace and evaluate the teaching and learning of Spanish language was settled at the Faculty of Applied Communication (FAC), Multimedia University (MMU). This assessment used inclusion criteria stated in the Spanish language curriculum framework for teaching Spanish for beginners under the requirements of this faculty. See table 6 Spanish Language Course Academic Requirements and the (videos 1, 2, 3 Conversational Spanish) from Spanish language novice learners to have linguistic-references about the effectiveness of the methodological perspective presented in this research-study:

Table 6: Spanish Language Course Academic Requirements

\begin{tabular}{|c|c|c|c|}
\hline \multicolumn{4}{|c|}{ Faculty Teaching and Learning Spanish Language Requirements } \\
\hline Syllabus & 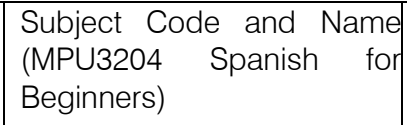 & $\begin{array}{l}\text { Course Objective, Justification } \\
\text { and Learning Outcome }\end{array}$ & $\begin{array}{l}\text { Number of Studs (40 } \\
\text { per class) } \\
\text { capacity }\end{array}$ \\
\hline Lecturer Plan & 12 Lessons & Delivering Mode Detailed & \\
\hline $\begin{array}{l}\text { Course Coursework } \\
\text { Specifications }\end{array}$ & Subject Knowledge Domains & Delivering Mode Detailed & \\
\hline
\end{tabular}

[Video 1: Conversational Spanish]

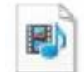

VID20191002161816.mp4

[Video 2: Conversational Spanish]

VID20200221144837.mp4

[Video 3: Conversational Spanish] 


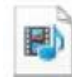

\section{VID20200221145059.mp4}

\section{Result and Discussion}

As a result of using the principles of the research techniques previously detailed, it was possible to determine the facts of the research-elements presented in the manuscript which are based on the research purpose: 1) Research methodology. 2) Subject matter domain. 3) Results and discussion. 4 ). Thus, the results obtained are of great value and have been presented clearly and consistently to these four parameters. In this respect, the study relates to a Spanish language teaching and learning settingprogram conducted at Faculty of Apply Communication (FAC), Multimedia University to expose a unique pedagogical perspective for treating the acquisition of Spanish language writing and speaking skills when working with Spanish novice learners whose second language is English. Taken into considerations these accounts, the research study has addressed the subject matter domain discussed throughout the research framework, matching that way the main objective of the research study. By taking as reference point the writing and speaking skills treatment the study has outlined in a comprehended manner the degree of languages complexities to be considered when teaching Spanish novices learners. Issues regarding Spanish Writing; Speaking; Syntax; Lexicon; Sentence construction; Pragmatic; Phonetic have been presented in the literature-content of this research-study to highlight the benefits that can be derived from this conceptualization in language practices. Insights based on this aim have been discussed bring out the significance of being wellprepared methodologically and linguistically as Spanish language teachers. In this respect, this study has presented linguistic and methodological ways for Spanish language teachers to successfully integrate and deliver assignments based on the acquisition of Spanish writing and speaking skills in the language class, mitigating the perceived need of producing Spanish language novice learners able to write with accuracy, clarity and coherence phrases and sentences into Spanish language contextual dialogues and paragraphs; make Spanish language novice leaners delivering phrases and sentences into spoken discourses with clearness in terms of pronunciation, fluency, coherence and through which they can demonstrate command of Spanish linguistic capabilities; and acknowledging the need to examine our Spanish language teachers' expertise. So, as Spanish language teachers we have to consider all these variants when threatening the writing and speaking skills. This will not be as difficult as many could think. The linguistic and methodology insights provided in this research-study are meant to excel the Spanish language teaching and learning in this regard. These insights are the result of studying the use of cognitive, meta-cognitive and affective components of learning to review the significance of teaching and learning approaches for Spanish language. Cognitive learning activities help students to process and critically analyze the provided information and contribute in the strengthening of their knowledge pertaining to that arena. Affective learning approaches are used by students to deal with the emotional responses that follow the learning process (Boekaerts, 1995). The metacognitive component of learning is involved in the exertion of control and responsibility over one's cognitive and affective processes in order to understand the information provided (Iran, 1990); (Zimmerman \& Bandura). Thus, learning is comprised of these three components, cited by (Vermunt \& Verloop, 1999).

\section{Xi. Recommendation}

Other than being a research study to set to solve all the complexities of linguistic functions with which Spanish language teachers and Spanish novice learners have to deal when it comes to the acquisition of the writing and speaking skills in Spanish language context; this research study has delivered possible solutions for setting appropriate teaching and learning Spanish language strategies to treat these two language competences. The significant impact that these two skills have on language productivities is astounding. Thus, further research studies in the field of Spanish language teaching and learning writing and speaking skills must be conducted to prepare Spanish language teachers and Spanish language novice learners to address a much more complex language teaching and learning situations created by this specific field of Applied Linguistics.

\section{Xil. Conclusion}

In conclusion, one could say that the manuscript presented contains significant literature sources corresponding to the main objective of the research study. From the perspective of language teaching and learning, significant Spanish language and methodological results can be obtained for Spanish language teachers to deliver assignments based on the acquisition of the writing and speaking skills in a Spanish language context. Based on these accounts, the research procedure applied permitted to properly displace throughout the headings and subheadings of the manuscript all the cited literature content in conjunction with its objective. Thus, this manuscript is a 
modest contribution to the field of Applied Linguistics and as such it lets at the disposition of the readers and the specialized critics for its evaluation.

\section{BIOGRAPHY}

1. American Council on the Teaching of Foreign Languages, 2012 (ACTFL) https://www.actfl.org/ publications/guidelines-and-manuals/actfl-proficiencyguidelines-2012

2. August, D., Calderón M., \& Carlo M. (2002) The Transfer of Skills from Spanish to English: A Study of Young Learners. Center for Applied Linguistics, Washington, D.C.

3. Ana C, Jarvis Raquel Lebredo, Framcisco MenaAyllnón (2014) Basic Spanish.

4. Alfredo Gonzales Hermoso, A. Carlos Romero Dueñas, C. (2015) (((Eco))) A1. Madrid: Grupo Didascalia.

5. Bialystok, E. (1981). «The Role of Linguistic Knowledge in Second Language Use». En Studies in Second Language Acquisition, 4, pp. 31-45.

6. Batchelor, R[onald] E[rnest]; San José, Miguel Ángel (2010), A Reference Grammar of Spanish, Cambridge University Press

7. Boekaerts, M. Self-regulated learning: Bridging the gap between metacognitive and metamotivation theories. Educational Psychologist, (1995) 30(4), 195-200.

8. Castañeda, A. (1997). Aspectos cognitivos en el aprendizaje de una lengua extranjera. Granada: Lingüística y Método.

9. Consejo de Europa (2001). Marco Común Europeo de Referencia para las Lenguas: aprendizaje, enseñanza, evaluación. (.http://cvc.cervantes.es/ obref/marco).

10. (Diccionario de la lengua española) $23^{a}$ Edición, 2015). Madrid: Espasa. ISBN 978-84-670- 4189-7.

11. Ehsan Namaziandost, Akram Abdi Saray, Fariba Rahimi Esfahani (2018). The Effect of Writing Practice on Improving Speaking Skill among Preintermediate EFL Learenrs DOI: http://dx.doi.org/ 10.17507/tpls.0812.16

12. Fathali, S., \& Sotoudehnama, E. (2015). The impact of guided writing practice on the speaking proficiency and attitude of EFL elementary learners. The Journal of Teaching Language Skills (JTLS), 7 (1), 1-25.

13. Hughes, R. (2013). Teaching and researching: speaking (2nd ed.). New York, NY: Routledge.

14. Hyland, K. (2003). Second language writing. Cambridge: Cambridge University Press.

15. Iran-Nejad, A. Active and dynamic self-regulation of learning processes. Review of Educational Research, (1990) 60(4), 573-602.

16. Marco Común Europeo de Referencia para las Lenguas: aprendizaje, enseñanza, evaluación.
Consejo de Europa (2001). https://www. examenglish.com/CEFR/cefr_es.php

17. Rutherford, W. y M. Sharwood Smith (Comps.) (1988). Grammar and Second Language Teaching. A Book of Readings. Massachussets: Newbury House.

18. Rivers, W. M. (1981). Teaching foreign language skills (2nd ed.). Chicago: University of Chicago Press.

19. Rivera, J. (2019) Spanish Language Grammatical Context-Acknowledging Specific Language Characteristics. Open Journal of Modern Linguistics, 9, 215-228. doi:10.4236/ojml.2019. 93020.

20. RIVERA, Joel Laffita. Orthography Analysis-Spanish Graphical Accentuation Setting. International Journal of Contemporary Education, [S.I.], v. 2, n. 2, p. 130-137, sep. 2019. ISSN 2575-3185.

21. Tengku Sepora Tengku Mahdi; Thomas Chow Voon Foo; Judul (2017). Language Teaching, Pedagogy and Curriculum Design e-ISNN 978-461-112-2

22. Silva, T.(1990). Second language composition instruction: Development, issues, and directions in ESL. In B. Kroll (Ed.), Second language writing: Research insights for the classroom (pp.11- 23). New York, NY: Cambridge University Press.'

23. Virgilio Borobio, V. (2015) Nuevo ELE Inicial 1. Madrid: Ediciones SM.

24. Vermunt, J. D., \& Verloop, N. Congruence and friction between learning and teaching. Learning and instruction, (1999) 9(3), 257-280.

25. Zimmerman, B. J., \& Bandura, A. Impact of selfregulatory influences on writing course attainment. American Educational Research Journal, (1994) 31(4), 845-862.

\section{ACKNOWLEDGEMENT}

The author is very thankful to all the associated personnel in any reference that contributed in/for the purpose of this research.

Conflit of Interest

The research holds no conflict of interest.

\section{Monetary Funding}

The research is not funded through any monetary source other than being sponsored by the professional interest of its author. 